\title{
Cold Start with Ethanol-Blend Fuels and Influences on Non-Legislated Emissions of a GDI Flex Fuel Vehicle
}

\author{
Zbigniew Stępień ${ }^{1 *}$, Jan Czerwinski ${ }^{2}$ \\ 'Performance Testing Department, Oil and Gas Institute - National Research Institute, \\ 25A Lubicz St., 31-503 Krakow, Poland \\ ${ }^{2}$ AFHB Laboratories for IC-Engines and Exhaust Emission Control, University of Applied Sciences Biel-Bienne, \\ 5 Gwerdtstrasse St. CH-2560 Nidau, Switzerland
}

Received: 21 January 2017

Accepted: 3 March 2017

\begin{abstract}
Using bioalcohols as a renewable energy source to substitute a part of fossil energy traffic and increasing the sustainability of individual transportation are important objectives in several countries. The global share of Bioethanol used for transportation is continuously increasing. Ethanol is a biomass-based renewable fuel that can be produced by alcoholic fermentation of sugar beet, sugar can, corn, and wheat (bio-ethanol), although petro-ethanol also exists, i.e., ethanol produced from fossil fuels. In the present tests we performed repeated cold starts performed with all investigated fuels, in two temperature ranges approaching $0^{\circ} \mathrm{C}$ and $20^{\circ} \mathrm{C}$ and with online measurement of different legislated and non-legislated emission components. The investigated fuel contained ethanol (E), in the portions of $10 \%$ and $85 \%$ by volume. The investigated vehicle represented a newer state of technology and an emission level of Euro 5. The engine works with homogenous GDI concept and with 3-W-catalyst (3WC). Since there is a special concern about the particle emissions of gasoline cars with direct injection, the nanoparticle counts measurements were systematically performed. The non-legislated gaseous emissions were tested at the tailpipe with FTIR, this with special focus on $\mathrm{NH}_{3}$, $\mathrm{HCHO}$ (formaldehyde), and $\mathrm{MeCHO}$ (acetaldehyde).
\end{abstract}

Keywords: ethanol blend fuels, cold start, non-legislated emissions, GDI flex fuel vehicle

\section{Introduction}

Thanks to the development of very powerful and reliable electronic control systems, in recent years a gasoline-ethanol operation up to E85 is possible in flex fuel vehicles (FFV). The engine electronic control unit

*e-mail: stepien@inig.pl recognizes automatically the portion of ethanol and adapts the parameterization of the engine calibration, respectively, to obtain the desired performance and emissions below legal limits. Information about ethanol content after each tank filling is provided by an Ethanol-sensor, [1] together with the OBD-control of the Lambda regulation, [2-4]. In the tested vehicle in this work we did not use an Ethanol sensor, but instead a PE (percentage ethanol) adaptive algorithm of the ECU.

Several manufacturers have introduced the FFV 
variants and published extensive information about their R\&D and performance: GM/Saab [2-3], Toyota [4], and VW [5]. The durable operation with ethanol needs several precautions: improvements of materials and surfaces of parts of combustion chamber, all plastic materials having contact with fuel, and the fuel and injection system. Functions of the electronic control of the engine have to be adapted to consider the changing heat value of the fuel and different oxygen content while changing the ethanol portion during refueling.

The use of ethanol interferes with lube oil and causes a quicker degradation of lubricating and cleaning properties [6-8].

In long-term operation deposits are formed in the injectors, in the intake manifold, on the intake valves, and in the combustion chamber. These deposits are prevented by special additives to the fuel, which in turn have to be developed and adapted for operation with ethanol [9-10].

Cold start and especially winter cold start is more difficult with higher ethanol content in the fuel due to the narrow evaporation range. The solutions are: doubletank-system (Brazilian market) or electrical preheating of engine and of the fuel system (EU \& US markets) [3, 11].

Increasing the ethanol portion in fuel results in higher oxygen content, and the effects are similar to the leaning of the engine operation. The legislated $\mathrm{CO}$ and $\mathrm{HC}$ gaseous emissions are usually reduced [12-14]. The influence on $\mathrm{NO}_{\mathrm{x}}$ can be different depending on the range of the equivalence ratio Lambda and in modern engines depending on the parameter setting of the ECU (first of all the spark timing).

The nanoparticles (NP) were previously a nonlegislated emission component, but they became an important research topic since the first introduction of legal nanoparticle count limits (Euro 5b) for DI SI passenger cars in EU beginning in 2013.

In this situation the NP and especially the metal oxide emissions from additive packages of lube oils and fuels become an important subject for all kinds of engines. Lube oil contributes to NP emissions, especially at cold start [15-19]. These new aspects were investigated with ethanol blend fuels Exx.

Investigations of particle emissions of light-duty vehicles (GDI and MPI) during winter cold start (in the range of $-8^{\circ} \mathrm{C}$ ) revealed that most of the total exhaust particles were solid soot and only a small fraction were semi-volatile [20].

Important knowledge about soot (particle) formation and control "in cylinder" was contributed by experimental research with optical access to the combustion chamber $[21,22]$. The portion of fuel which during the combustion process stays on the combustion chamber wall is incompletely burned and is a major source of (nano) particles. This fuel portion can of course interact with the lube oil layer (on the wall) and implicate parts of lube oil in this incomplete combustion. The application of an oxygenated fuel tendentiously improves oxidation and partially compensates for the drawbacks of the imperfect mixture preparation.
Further gaseous substances, which may be present under certain conditions in very low concentrations in the exhaust gases, are considered to be potential candidates for future legal limitation. These non-legislated emission components are: ammonia $\left(\mathrm{NH}_{3}\right)$, nitrogen dioxide $\left(\mathrm{NO}_{2}\right)$, and nitrous oxide $\left(\mathrm{N}_{2} \mathrm{O}\right.$; also called together with $\mathrm{NO}$ as $\mathrm{RNC}$... reactive nitrogen compounds), rormaldehyde ( $\mathrm{HCHO})$, and acetaldehyde (MeCHO) - all of which are quite easy measured and indicated with FTIR.

Production of ammonia $\left(\mathrm{NH}_{3}\right)$ in the exhaust of gasoline cars with $3 \mathrm{WC}$ was demonstrated in [23-26], especially at transient operations with rich excursions of Lambda. The development of the catalyst washcoat, its oxygen storage capacity, and the dynamic accuracy of Lambda regulation are important tools for minimizing the Lambda excursions during transients, and with that to reduce the peaks of: $\mathrm{NO} / \mathrm{NO}_{\mathrm{x}}$ in lean and $\mathrm{NH}_{3}$ in rich deviations, [23, 27].

Nitrous oxide $\left(\mathrm{N}_{2} \mathrm{O}\right)$ was focused by the U.S. EPA as a greenhouse gas of a very high potential [28-29] and has started to be investigated by some researchers [25-26, 3031].

The aldehydes ( $\mathrm{HCHO}$ and $\mathrm{MeCHO}$ ) as products of an incomplete oxidation of alcohols are supposed to produce peak concentrations at cold start.

All the gaseous non-legislated components were little investigated in connection with E85 operation. From the research of the authors we can state that with a correctly working 3WC (at warm operation of the presented FFV vehicle) there are usually no measurable concentrations of $\mathrm{NO}_{2}$ and $\mathrm{N}_{2} \mathrm{O}$, and the $\mathrm{HCHO}$ values show noise below 1 ppm [12].

\section{Material and Methods}

The tests were performed with a new (Euro 5) flex fuel vehicle Volvo V60 GDI (gasoline direct injection), which is a reference vehicle for several projects concerning NP (nanoparticles $<999 \mathrm{~nm}$ ) research from gasoline engines (Table 1).

The gasoline used was from the Swiss market, RON (research octane number) 95, according to SN EN228. For the tests a charge of fuel was purchased to maintain the unchanged chemistry.

As further variants we used ethanol blend fuels E10 and E85. These are respectively blends with $90 \%$ by volume gasoline and $10 \%$ by volume ethanol, or with $15 \%$ by volume gasoline and $85 \%$ by volume ethanol. The blend fuels were prepared on the basis of E85 purchased on the Swiss market. Table 2 summarizes the most important parameters of the fuels.

The tests were performed on a chassis dynamometer (Schenk 500 GS 60) with a CVS (constant volume sampling) system (Horiba CVS-9500 T) and with the exhaust gas measuring system for legislated components (Horiba MEXA-9400H). The non-legislated gaseous components were analyzed with FTIR (Fourier transform infrared analyzer) measuring raw emissions at the 
Table 1. Data of tested vehicle.

\begin{tabular}{|c|c|}
\hline Vehicle & $\begin{array}{c}\text { Volvo V60 } \\
\text { T4F }\end{array}$ \\
\hline Engine code & B4164T2 \\
\hline Number and arrangement of cylinder & $4 /$ inline \\
\hline Displacement cm ${ }^{3}$ & 1596 \\
\hline Power kW & $132 @ 5700 \mathrm{rpm}$ \\
\hline Torque Nm & $240 @ 1600 \mathrm{rpm}$ \\
\hline Injection type & DI \\
\hline Curb weight kg & 1554 \\
\hline Gross vehicle weight kg & 2110 \\
\hline Drive wheel & Front-wheel drive \\
\hline Gearbox & a6 \\
\hline First registration & 27.01 .2012 \\
\hline Exhaust & EURO 5a \\
\hline
\end{tabular}

tailpipe. An FTIR spectrometer (AVL SESAM) offers the possibility of simultaneous, time-resolved measurement of approx. 30 emission components, including: $\mathrm{NO}, \mathrm{NO}_{2}$, $\mathrm{NOx}, \mathrm{NH}_{3}, \mathrm{~N}_{2} \mathrm{O}, \mathrm{HCN}, \mathrm{HNCO}, \mathrm{HCHO}, \mathrm{MeCHO}$, and ETOH.

The presented THC results originate from the CVS FID (flame ionization detector) and do not involve the correction for ETOH content from FTIR. Nanoparticles were measured with SMPS (scanning mobility particle sizer) in three phases of the test duration and online with CPC (condensation particle counter) - SMPS: DMA (differential mobility analyzer) TSI 3081 and CPC TSI $3772(9.8-429 \mathrm{~nm})$.

For dilution and sample preparation we used an ASET (system of aerosol sampling and evaporation tube) containing:

- Primary dilution air: MD19 tunable minidiluter (Matter Eng. MD19-2E).

- Secondary dilution air: dilution of the primary diluted and thermally conditioned measuring gas on the outlet of evaporative tube.
- Thermoconditioner (TC): sample heating at $300^{\circ} \mathrm{C}$.

For cold starts (CS), two ranges of start temperature were considered: summer cold start $\left(20\right.$ to $25^{\circ} \mathrm{C}$, conditioning in the test hall), or mild winter cold start ( -2 to $4^{\circ} \mathrm{C}$, conditioning outside in the cold-weather period). For simplification of titles and descriptions these temperature ranges will be designed as $20^{\circ} \mathrm{C}$ and $0^{\circ} \mathrm{C}$.

In the preliminary tests with gasoline two variants of cold start were investigated:

a) Cold start at idling (without chassis dynamometer).

b) Cold start with acceleration to $20 \mathrm{~km} / \mathrm{h}$ and $\mathrm{v}=$ const. $=20 \mathrm{~km}$ on the chassis dynamometer; braking resistances were set according to legal prescriptions and they responded to the horizontal road.

It was stated after this test period that the CS on chassis dynamometer (with $20 \mathrm{~km} / \mathrm{h}$ ) does not bring any further information potentials, and further research was generally limited to the CS at idling.

The vehicle, which was conditioned outside for the mild winter CS, was pushed into the test hall, attached to the measuring systems, started, and operated in the conditions of the hall (intake air $20-25^{\circ} \mathrm{C}$ ). After the test, the vehicle was conditioned by driving an NEDC (new European driving cycle) on the chassis dynamometer.

\section{Results and Discussion}

The emission results are represented as time-courses during the cold start (CS) and warm-up phase until $10 \mathrm{~min}$. after start. Each configuration of CS was performed at least three times and the represented plots are averages from three attempts. The results from single days (not represented here) show repetitive tendencies with certain fluctuation of peak values. Figs 1 and 2 show gaseous emissions, comparing ethanol blend fuels E0/E10/E85 in two temperature domains of the $\mathrm{CS}: 0^{\circ} \mathrm{C}$ and $20^{\circ} \mathrm{C}$.

The values of $\mathrm{CO}, \mathrm{HC}, \mathrm{HCHO}$ (formaldehyde) and ETOH (ethanol) have generally a strong peak in the first $60-80 \mathrm{~s}$ after start. At higher start temperature $\left(20^{\circ} \mathrm{C}\right)$ these peak values are lower. For $\mathrm{CO}$ and $\mathrm{HC}$ there is no tendency of peak values considering the fuel quality (E0/E10/E85). The peak values of $\mathrm{HCHO}$ and of $\mathrm{ETOH}$ nevertheless are with E85 the highest.

Table 2. Parameters of used fuels.

\begin{tabular}{|c|c|c|c|c|c|c|}
\hline & & Gasoline & $\begin{array}{c}\text { Ethanol } \\
\mathrm{C}_{2} \mathrm{H}_{5} \mathrm{OH}\end{array}$ & $\begin{array}{c}\mathrm{n}-\mathrm{Butanol} \\
\mathrm{C}_{4} \mathrm{H}_{10} \mathrm{O}\end{array}$ & E10 & E85 \\
\hline Density $15^{\circ} \mathrm{C}$ & {$\left[\mathrm{g} / \mathrm{cm}^{3}\right]$} & 0.737 & 0.789 & 0.806 & 0.742 & 0.781 \\
\hline Stoichiometric air/fuel ratio & {$[-]$} & 14.6 & 9.0 & 11.10 & 14.0 & 9.8 \\
\hline Lower calorific value & {$[\mathrm{MJ} / \mathrm{kg}]$} & 43.0 & 26.8 & 33.12 & 41.3 & 28.9 \\
\hline Oxygen content & {$[\% \mathrm{~m}]$} & 1.7 & 34.8 & 21.6 & 5.0 & 31.2 \\
\hline Boiling point & {$\left[{ }^{\circ} \mathrm{C}\right]$} & $30-200$ & 78.5 & 118 & $30-200$ & $30-200$ \\
\hline Research octane Nbr. & {$[-]$} & 95 & 110 & 99 & 97 & 108 \\
\hline Latent heat of evaporation & {$[\mathrm{kJ} / \mathrm{kg}]$} & 420 & 900 & 343 & 471 & 832 \\
\hline
\end{tabular}




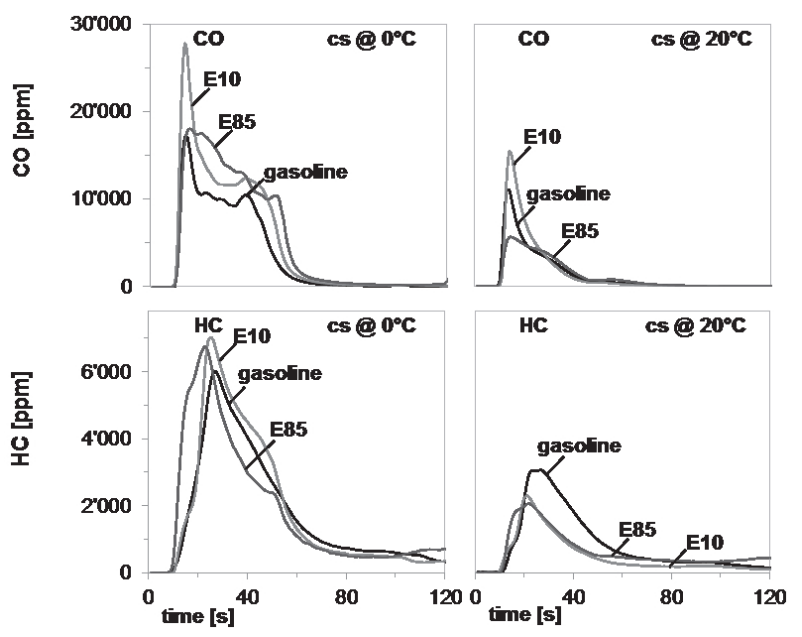

Fig. 1. Comparison of gaseous emissions during cold start at idling with different fuels, measured with FTIR at tailpipe.
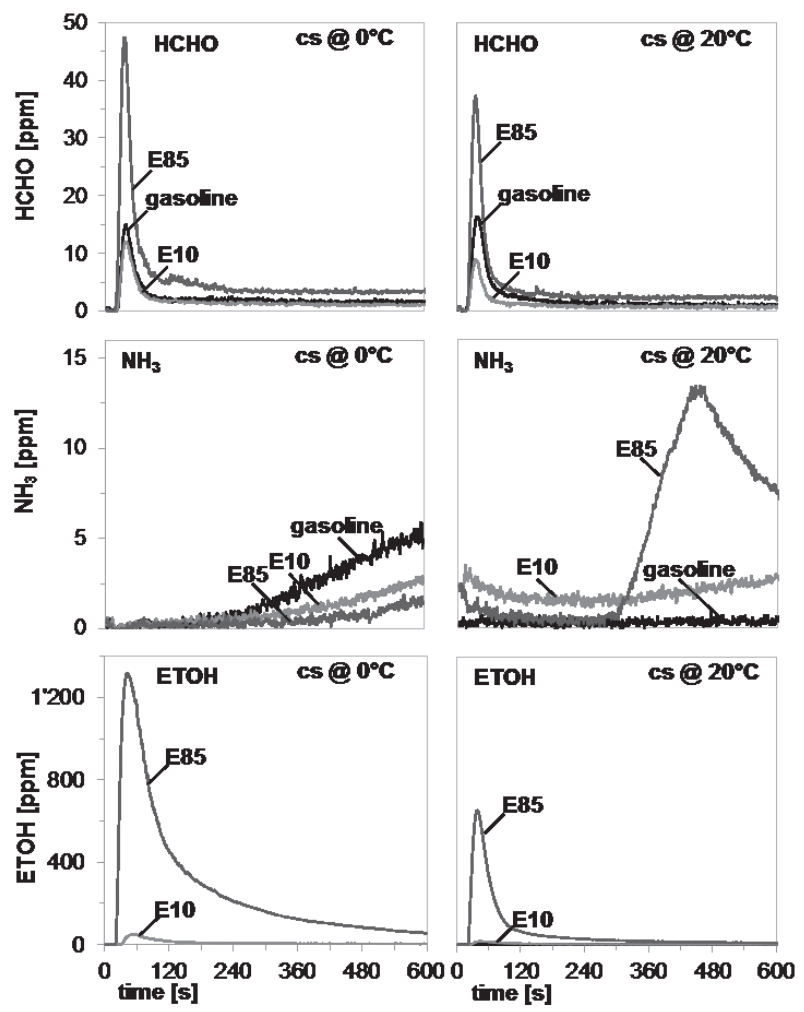

Fig. 2. Comparison of gaseous emissions during cold start at idle with different fuels, measured with FTIR at tailpipe.

$\mathrm{NH}_{3}$ is zero at start, but it increases during the warmup period up to $6 \mathrm{ppm}$ after $10 \mathrm{~min}$. The exception is with $\mathrm{E} 85$ at $20^{\circ} \mathrm{C}$, where $\mathrm{NH}_{3}$ has a stronger increase (up to $13 \mathrm{ppm})$. This is due to random conditions promoting $\mathrm{NH}_{3}$ production, like: dispersion of the engine emission profile, store-release effects in the exhaust system, local enrichment regions in the catalyst and/or heterogeneous heating of the catalyst. It is known from previous research [32] that certain $\mathrm{NH}_{3}$-peaks appear randomly even in repetitive driving conditions at warm operation.

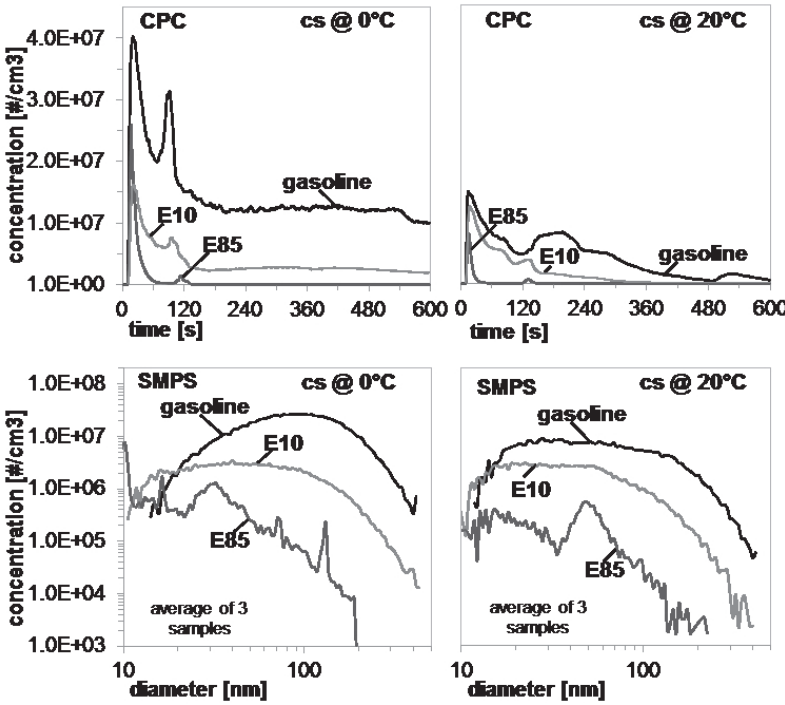

Fig. 3. Comparison of particle counts during cold start at idling with different fuels, measured with both systems at tailpipe.

Fig. 3 compares the nanoparticle emissions with the fuels $\mathrm{E} 0 / \mathrm{E} 10 / \mathrm{E} 85$ at $\mathrm{CS}$ in both temperature ranges $0^{\circ} \mathrm{C}$ and $20^{\circ} \mathrm{C}$. CPC (condensation particle counter) measures the particle numbers of all particle sizes according to the PMP-guidelines. SMPS (scanning mobility particle sizer) measures the particle numbers in function of their size.

The SMPS-particle size distributions were taken in the successive parts of the warm-up period: 1) 0-120 s, 2) $120-300 \mathrm{~s}$, and 3) 300-600 s.

The successive SMPS-scans of each CS-attempt (not represented here) clearly showed the lowest PC-level of the latest sample. The $1^{\text {st }}$ sample was well repeatable and the PSDs in Fig. 3 are averages from three cold starts of the first scan (in the period 0-120 s). The CPC signals at $0^{\circ} \mathrm{C}$ have a second peak after approximately $2 \mathrm{~min}$. This is visible particularly with gasoline (E0). This peak is a repeatable event, and it can also be found in other emission courses (like $\mathrm{N}_{2} \mathrm{O}$ ) and it is attributed to the changes introduced by the engine ECU in function of temperature, like possible catalyst heating, switching of internal EGR by vario cams, or heat management.

The most important information of Fig. 3 is that with increasing Exx-content of fuel the PN-emissions are significantly reduced. Also, the higher temperature of CS lowers the PN-values, which is clearly visible with the transient measuring method (CPC) and less visible with the quasi-stationary results (SMPS).

Fig. 4 shows production of $\mathrm{N}_{2} \mathrm{O}$ during the cold-start and warm-up phases. The peak values are considerable at $0^{\circ} \mathrm{C}$ (up to $45 \mathrm{ppm}$ with E0) and the highest peaks are not at start, but approximately $100 \mathrm{~s}$ after start $\left(\right.$ at $\left.0^{\circ} \mathrm{C}\right)$, provoked by the engine ECU. At $20^{\circ} \mathrm{C}$ the peak values with all fuels are nearly equal (10 ppm) and approx. $60 \mathrm{~s}$ after the start. It appears that the fuel quality at $20^{\circ} \mathrm{C}$ has no influence on the $\mathrm{N}_{2} \mathrm{O}$-values. At $20^{\circ} \mathrm{C}$ there are other maxima of $\mathrm{N}_{2} \mathrm{O}$ after 5-6 min. These maxima do not exist at $0^{\circ} \mathrm{C}$. 


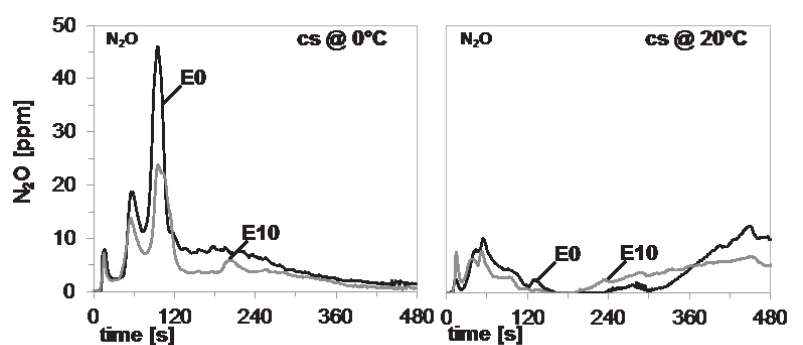

Fig. 4. $\mathrm{N}_{2} \mathrm{O}$-emissions at cold start with E0/E10.

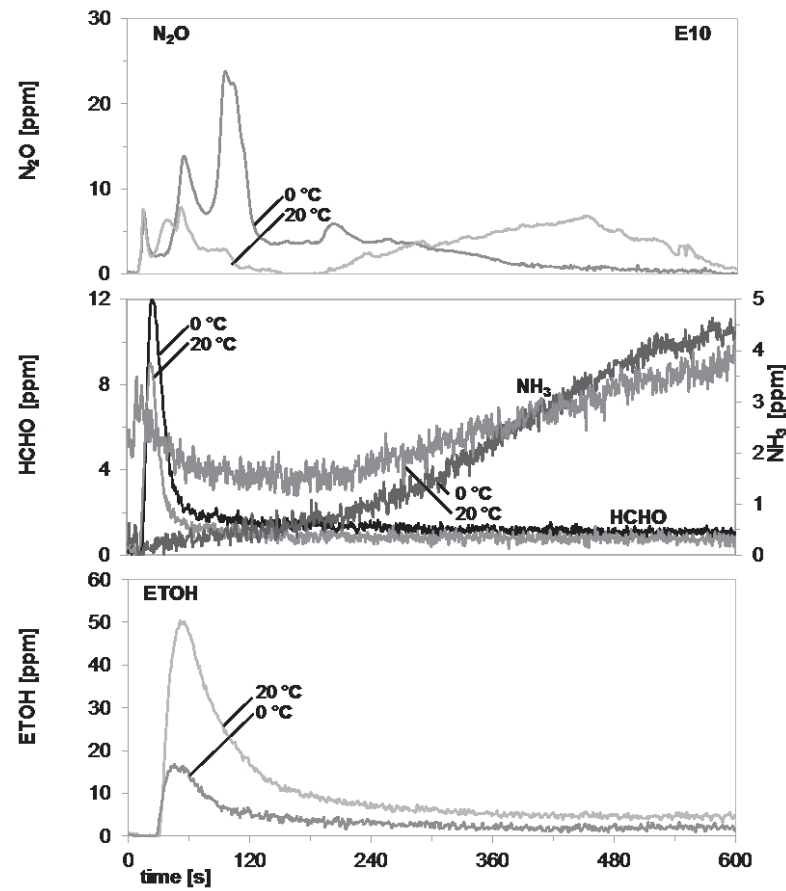

Fig. 5. Influence of start temperature $\left(0^{\circ} \mathrm{C}\right.$ and $\left.20^{\circ} \mathrm{C}\right)$ on exhaust emissions during cold start and warm-up at idling (example E10).
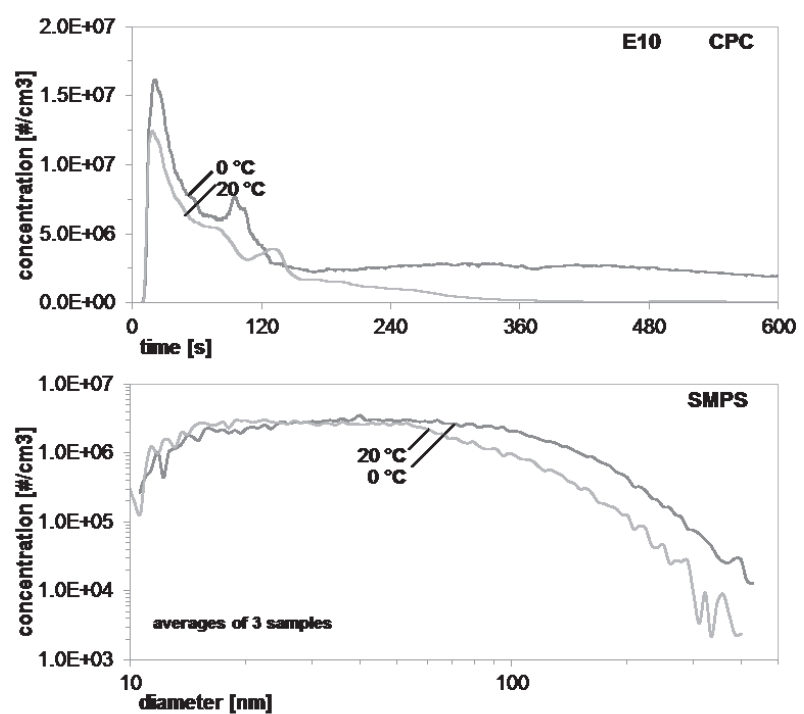

Fig. 6. Influence of start temperature $\left(0^{\circ} \mathrm{C}\right.$ and $\left.20^{\circ} \mathrm{C}\right)$ on nanoparticles during cold start and warm-up at idling (example E10).

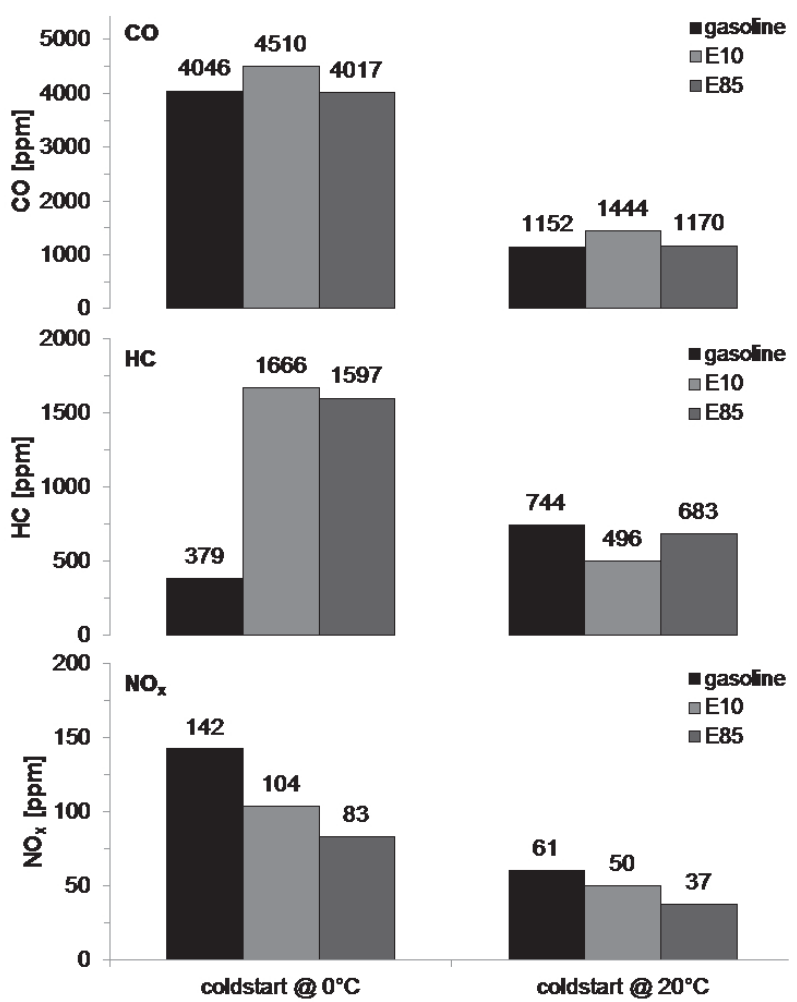

Fig. 7. Integral average values of exhaust emissions with different fuels in the first $2 \mathrm{~min}$. after cold start $\left(0^{\circ} \mathrm{C}\right.$ and $\left.20^{\circ} \mathrm{C}\right)$ at idling.

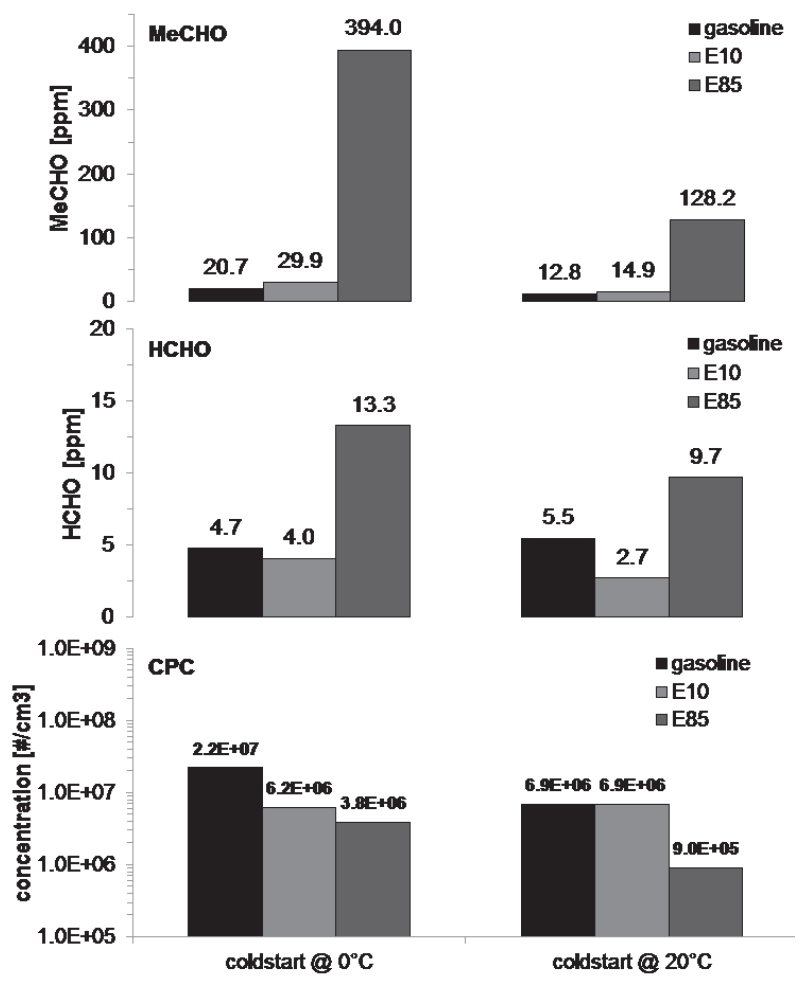

Fig. 8. Integral average values of gaseous and nanoparticle emissions with different fuels in the first $2 \mathrm{~min}$. after cold start $\left(0^{\circ} \mathrm{C}\right.$ and $20^{\circ} \mathrm{C}$ ) at idling. 
Figs 5 and 6 represent the influence of the cold start temperature as examples of some emission components with E10. With the lower temperature of CS there is a higher production of $\mathrm{N}_{2} \mathrm{O}, \mathrm{HCHO}, \mathrm{ETOH}$, and $\mathrm{PN}$ (CPC). This statement is also valid for the other components, which are represented in other figures of this paper: $\mathrm{CO}$, $\mathrm{HC}$, NOx, and MeCHO.

Generally the emission level is reduced with progressing warm-up from part 1 to part 3. Only $\mathrm{NH}_{3}$ behaves inversely and it has a tendency to increase during the warm-up.

Figs 7 and 8 summarize the emissions as integral average values in the first two minutes after CS. For CO, $\mathrm{HC}$, and NOx the emissions are lower at the higher start temperature. With increasing ethanol content the NOx values decrease. For non-legislated gaseous components there is a finding of considerable increased values of $\mathrm{MeCHO}$ and $\mathrm{HCHO}$ with E85.

\section{Conclusions}

From the obtained results the following statements have to be mentioned:

With higher Ethanol content there are:

- Higher peaks of formaldehyde (HCHO) and acetaldehyde (MeCHO) at start.

- A lower increase of $\mathrm{NH}_{3}$ after $600 \mathrm{~s}$ at $0^{\circ} \mathrm{C}$ and a higher increase of $\mathrm{NH}_{3}$ after $600 \mathrm{~s}$ at $20^{\circ} \mathrm{C}$.

- A lower NP value, both: average of CPC-and average of SMPS-signals.

With increased temperature at start $\left(20^{\circ} \mathrm{C}\right.$ instead of $\left.0^{\circ} \mathrm{C}\right)$ there are:

- Lower peaks of CO and NOx.

- Lower peaks of MeCHO and of HCHO.

- Lower peaks of ETOH.

- Lower peak values of $\mathrm{N}_{2} \mathrm{O}$ after start.

- Lower peaks of CPC and mostly lower SMPS PCconcentrations.

Regarding the warm-up period in three successive parts with increasing temperature level of the engine it can be noted that generally the emission level is reduced with progressing warm-up from parts 1 to 3 . Only $\mathrm{NH}_{3}$ behaves inversely, increasing after $540 \mathrm{~s}$ in some test series up to max. 6 ppm.

\section{Abbreviations}

AFHB - Abgasprüfstelle FH Biel, CH

ASET - Aerosol Sampling and Evaporation Tube

ASTRA - Amt für Strassen (CH)

BAFU - Bundesamt für Umwelt (FOEN)

BfE - Bundesamt für Energie (FOE)

CADC - Common Artemis driving cycle

CLA - Chemiluminescent analyzer

CLD - Chemiluminescent detector

CPC - Condensation particle counter

CS - Cold start
CVS - Constant volume sampling

DF - Dilution factor

DI - Direct injection

DMA - Differential mobility analyzer

ECU - Electronic control unit

EMPA - Eidgenössische Material Prüf- und Forschungsanstalt

EUDC - Extra urban driving cycle

EU - European Community

EV - Erdöl Vereinigung

FFV - Flex fuel vehicle

FID - Flame ionization detector

FOE - Federal Office of Energy

FOEN - Federal Office of the Environment

FTIR - Fourier transform infrared analyzer

GDI - Gasoline direct injection

HC - Unburned hydrocarbons

HCHO - Formaldehyde

HCN - Hydrocyanic acid

HNCO - Isocyanic acid

MD - Minidiluter

MS - Mass spectroscopy

NO - Nitrogen monoxide

$\mathrm{NO}_{2}$ - Nitrogen dioxide

$\mathrm{N}_{2} \mathrm{O}$ - Nitrous oxide

$\mathrm{NH}_{3}$ - Ammonia

NOx - Nitric oxides

NP $\quad$ - Nanoparticles $<999 \mathrm{~nm}$

OBD - On-board diagnostics

PC - Particle counts (integrated)

PMP - Particle Measuring Program of the GRPE

PN - Particle numbers

PSD - Particle size distribution

RON - Research octane number

SMPS - Scanning mobility particle sizer

SP - Sampling position

SSC - Steady state cycle

TC - Thermoconditioner

Texh - Exhaust gas temperature at tailpipe

THC - Total hydrocarbons

TPN - Total particle number

TWC - Three-way catalyst

ULSD - Ultra-low sulphur Diesel

VSS - Verband der Schweizerischen

Schmierstoffindustrie

WLTC - Worldwide harmonized light-duty test cycle

WLTP - Worldwide harmonized light-duty test procedure

3WC - Three-way catalyst

\section{References}

1. FAHRENBRUCH A., BACHMANN J. 1) Ethanol Sensors for Flex Fuel Operation. MTZ Sept. 9, 732, 2008.

2. BERGSTRÖM K., MELIN S.-A., JONES C. The New ECOTEC Turbo BioPower Engine from GM powertrain Utilizing the Power of Nature's resources. 28. Internationales Wiener Motoren-Symposium, Bd. 2, 47, 2007.

3. BERGSTRÖM K., NORDIN H., KÖNIGSTEIN A., 
MARRIOTT C., WILES M. ABC - Alcohol Based Combustion Engines - Challenges and Opportunities. 16. Aachener Kolloquium Fahrzeug- und Motorentechnik, Bd. 2, 1031, 2007.

4. KAWAI T., TSUNOOKA T., CHIBA F., UDA H., SONODA Y. Effect of High Concentration Ethanol on SI Engine Cold Startabillity and Emissions. 16. Aachener Kolloquium Fahrzeug- und Motorentechnik, Bd. 2, 1075, 2007.

5. HADLER J., SZENGEL R., MIDDENDORF H., SPERLING H., GRÖER H-G., TILCHNER L. $1.41118 \mathrm{~kW}$ TSI engine for E85 operation - the extension of the consumption-favorable spark-ignition engines line from Volkswagen. 32. Internationales Wiener Motorensymposium, Bd. 1, 263, 2011.

6. SCHWARZE H., BROUWER L., KNOLL G., LONGO C., KOPNARSKI M., EMRICH S. Effect of ethanol fuel E85 on lubricant degradation and wear in spark-ignition engines. MTZ, April 4, 286, 2010.

7. ARTMANN Ch., RABL H-P., FAULSTICH M. Online determination of lubricant oil dilution in spark-ignition engines. MTZ, Januar 1, 70, 2012.

8. KÜPPER C., ARTMANN Ch., PISCHINGER S., RABL H-P. Lube-oil dilution of spark-ignition direct-injection engines in cold start conditions. MTZ, September 9, 710, 2013.

9. DUMONT R. J., CUNNINGHAM L. J., OLIVER M. K., STUDZINSKI W. M., GALANTE-FOX J. M. Controlling Induction System Deposits in Flexible Fuel Vehicles Operating on E85. SAE Technical Paper 2007-01-4071, 2007.

10. GALANTE -FOX J.M., VON BACHO P., NOTARO C., ZIZELMAN J. E-85 Fuel Corrosivity: Effects on Port Fuel Injector Durability Performance. SAE Technical Paper 2007-01-4072, 2007.

11. GREFF A., BRANDL A., SCHULZE T., KAPPHAN F. Extended range of optimal combustion in flex-fuel operation. MTZ September 9, 668, 2011.

12. CZERWINSKI J., COMTE P., STEPIEN Z., OLEKSIAK S. Effects of Ethanol Blend Fuels E10 \& E85 on the NonLegislated Emissions of a Flex Fuel Passenger Car. SAE Technical Paper 2016-01-0977, 2016.

13. AGARWAL J., ALAM M., JAISWAL A., YADAV K., KUMAR N. Comparative Study of Emissions and Performance of Hythane Boosted SI Engine Powered by Gasoline-Ethanol Blend. SAE Technical Paper 2016-011281, 2016.

14. WANG X., GE Y., ZHANG CH., LIU J., PENG Z., GONG H.: Estimating Ozone Potential of Pipe-out Emissions from Euro-3 to Euro-5 Passenger Cars Fuelled with Gasoline, Alcohol-Gasoline, Methanol and Compressed Natural Gas. SAE Technical Paper 2016-01-1009, 2016.

15. CHAN T.W., MELOCHE E., KUBSH J., BREZNY R., ROSENBLATT D., RIDEOUT G. Impact of Ambient Temperature on Gaseous and Particle Emissions from a Direct Injection Gasoline Vehicle and its Implications on Particle Filtration. SAE Technical Paper 2013-01-0527, 2013.

16. SONNTAG D.B., BAILEY Ch.R., FULPER C.R., BALDAUF R.W. Contribution of Lubricating Oil to Particulate Matter Emissions from Light-Duty Gasoline Vehicles in Kansas City. Environment Science \& Technology, 27 (2), 4191, 2012.

17. PORTER S. Particle Number Emissions of Gasoline Hybrid Electric Vehicle. MTZ, April 4, 278, 2012.

18. BUTLER A.D., SOBOTOWSKI R.A., HOFFMAN G.J., MACHIELE P. Influence of Fuel PM Index and Ethanol
Content on Particulate Emissions from Light-Duty Gasoline Vehicles. SAE Technical Paper 2015-01-1072, 2015.

19. EIFLER G., NEUMANN R., HERZBERGER C. Particulate Emission Development at SI- Engines for Future RDEDemand. 9th International Exhaust Gas and Particulate Emissions Forum 23/24 February, 168, 2016, Ludwigsburg, Germany.

20. BADSHAH H., KITTELSON D., NORTHROP W. Particle Emissions from Light-Duty Vehicles during Cold-Cold Start. SAE Technical Paper 2016-01-0997, 2016.

21. MIKLAUTSCHITSCH M., DURST B., GIERL R., RUBBERT S., UNTERWEGER G., PHILIPP H. Experimental analysis of soot formation in BMW TwinPower Turbo Engines by Simultaneous Use of HighSpeed Endoscopy and Fiberoptic Instrumented Spark Plug. 12th International Symposium on Combustion Diagnostics, May $10^{\text {th }} / 11^{\text {th }}, 36, \mathbf{2 0 1 6}$, Baden-Baden, Germany.

22. LUCACHICK G., AVENIDO A., WATTS W., KITTELSON D., NORTHROP W. Efficacy of In-Cylinder Control of Particulate Emissions to Meet Current and Future Regulatory Standards. SAE Technical Paper 2014-01-1597, 2014.

23. HEEB N., FORSS A-M., BRÜHLMANN S., LÜSCHER R., SAXER Ch., HUG P. Three-Way Catalyst-Induced Formation of Ammonia - Velocity- and AccelerationDependent Emission factors. Elsevier, Atmospheric Environment, 40, 5986, 2006.

24. HEEB N., SAXER Ch., FORSS A-M., BRÜHLMANN S. Trends of NO-, $\mathrm{NO}_{2}-$, and $\mathrm{NH}_{3}$-Emissions from GasolineFueled Euro-3-to Euro-4-Passenger Cars. Elsevier, Atmospheric Environment, 42, 2543, 2008.

25. WOODBURN J., BIELACZYC P., SZCZOTKA A. Chassis Dynamometer Testing of Ammonia Emissions from LightDuty SI Vehicles in the Context of Emissions of Reactive Nitrogen Compounds. SAE Technical Paper 2013-01-1346, 2013.

26. BIELACZYC P., SZCZOTKA A., WOODBURN J. An Overview of Emissions of Reactive Nitrogen Compounds from Modern Light Duty Vehicles Featuring SI Engines. Combustion Engines, 159 (4), 48, 2014.

27. STEWART J.D., STALKER R.M., O'SHAUGHNESSY R., DOUGLAS R., WOODS A. Sensitivity Analysis of Full Scale Catalyst Response under Dynamic Test-ing Conditions A Method to Develop Further Understanding of Catalytic Converter Behavior Pt. 1. SAE Technical Paper 2016-010979, 2016

28. United States Environmental Protection AgencyOverview of Greenhouse Gases: $\mathrm{N}_{2} \mathrm{O}$, http://www.epa.gov/ climatechange.

29. United States Environmental Protection Agency, Light-Duty Vehicle Greenhouse Gas Emission Standards and Corporate Average Fuel Economy Standards; Final Rule, Federal Register/Vol. 75 (88), 2010.

30. BORSARI V., DE ASSUNÇÃ J. Nitrous Oxide Emissions from Gasolhol, Ethanol and CNG Light Duty Vehicles 2012, doi: 10.1007/s10584-011-0203-9.

31. GRAHAM L.A., BELISLE S.L., RIEGER P. Nitrous Oxide Emissions from Light Duty Vehicles, Atmospheric Environment, 43, 2031, 2009. doi: 10.1016/j. atmosenv.2009.01.002.

32. CZERWINSKI J., COMTE P., GÜDEL M., LEMAIRE J., MAYER A., HEEB N., BERGER H., REUTIMANN F. Investigations of Emissions of Reactive Substances $\mathrm{NO}_{2}$ and $\mathrm{NH}_{3}$ from Passenger Cars. PTNSS Journal Combustion Engines No. 166 (3), 17, 2016. 